Sara Nisula

Kirsi-Maija Kaukonen

Suvi T. Vaara

Anna-Maija Korhonen

Meri Poukkanen

Sari Karlsson

Mikko Haapio

Outi Inkinen

Ilkka Parviainen

Raili Suojaranta-Ylinen

Jouko J. Laurila

Jyrki Tenhunen

Matti Reinikainen

Tero Ala-Kokko

Esko Ruokonen

Anne Kuitunen

Ville Pettilä

The FINNAKI Study Group

\section{Erratum to: Incidence, risk factors and 90-day mortality of patients with acute kidney injury in Finnish intensive care units: the FINNAKI study}

Published online: 24 January 2013

(C) Springer-Verlag Berlin Heidelberg and ESICM 2013

The online version of the original article can be found under doi:10.1007/s00134-012-2796-5.

S. Nisula ( $)$ K.-M. Kaukonen · S. T. Vaara ·

A.-M. Korhonen · R. Suojaranta-Ylinen · V. Pettilä

Division of Anaesthesia and Intensive Care Medicine Department of Surgery, Intensive Care Units, Helsinki University Central

Hospital, Box 340, 00029 HUS Helsinki, Finland

e-mail: sara.nisula@hus.fi

\section{Poukkanen}

Department of Anesthesia and Intensive Care Medicine,

Lapland Central Hospital, Rovaniemi, Finland

S. Karlsson · M. Reinikainen

Department of Intensive Care, North Karelia Central Hospital, Joensuu, Finland

\section{S. Karlsson $\cdot$ J. Tenhunen $\cdot$ A. Kuitunen} Department of Intensive Care Medicine,

Tampere University Hospital, Tampere, Finland

\section{Haapio}

Department of Nephrology, Helsinki University Central Hospital, Helsinki, Finland

\section{O. Inkinen}

Department of Anesthesia and Intensive Care Medicine,

Turku University Hospital, Turku, Finland
I. Parviainen · E. Ruokonen

Division of Intensive Care, Kuopio University Hospital, Kuopio, Finland

\section{J. J. Laurila · T. Ala-Kokko}

Division of Intensive Care, Department of Anesthesiology, Oulu University Hospital, Oulu, Finland

\section{Pettilä}

Institute of Clinical Medicine, University of Helsinki, Helsinki, Finland

\section{Erratum to: Intensive Care Med DOI 10.1007/s00134-012-2796-5}

Through no fault of the authors, the manuscript received by the publisher contained two incorrect references. The correct references are as follows:

5. Kidney Disease: Improving Global Outcomes (KDIGO) Acute Kidney Injury Work Group (2012) KDIGO Clinical Practice Guideline for Acute Kidney Injury. Kidney Int Suppl 2:1-138

15. Finnish Registry for Kidney Diseases: Report 2010 and Report 2011 (unpublished data) 